๖ Open Access Journal

Review Article

\title{
Chronic cervical cancer pain and radiotherapy
}

\author{
Vania Sukarno \\ Undergraduate Medicine Programme, Medical \\ Faculty, Udayana University
}

\section{Introduction}

Cervical cancer has the most frequent complications in the form of chronic pain, likewise the connection with the use of radiotherapy for cervical cancer. ${ }^{1}$ Chronic pelvic pain after radiotherapy is frequently reported in long term cervical cancer, which is defined as pain that has a longer duration than the natural healing time that can be located in the lower back, groins, or hips. The characteristic of the pain can be radiated, persists in either rest or activity, and affecting daily activity. Many studies on chronic cervical cancer pain are usually directed on insufficiency fractures, ${ }^{2,3}$ proctitis, cystitis, and chronic radiation enteritis frequently reported..$^{4-7}$ Other complications of the pelvic radiation are osteoradionecrosis, burning perineum syndrome, lymphedema pain, myelopathy of chronic radiation, and plexopathies of lumbosacral. Most patients will suffer from chronic pain with obvious pathology. ${ }^{8}$ However, the diagnosis may be considered if the patient's symptoms are not due to other gynecological problems. It's important to identify patients suffering from pain related to the cause. The Pain is usually only rated as a problem from the list of symptoms, which often complained as regular back pain. While the pain itself has been shown to reduced the quality of life, not many studies have looked at its relationship with radiotherapy. ${ }^{5}$ This review was made for this purpose.

\section{Cervical cancer}

Cervical cancer is a malignancy originating from the cervix. The cervix is the lower third of the uterus, cylindrical, protruding and connected to the vagina through the external uterine ostium. ${ }^{9}$ An estimated number of 454,000 cervical cancer incidents was obtained from registration and verbal autopsy from 1980 to $2010 .{ }^{10}$ A study conducted in India stated incidence of cervical cancer increased by $3.1 \%$ every year from 2001 to $2011 .{ }^{11}$

According to Ferlay et al in 2014, cervical cancer ranks the 7th largest incidence globally and 8 th as the largest cause of death (mortality is at $3.2 \%$, the same as leukaemia). ${ }^{12}$ In Indonesia, cervical cancer is the second highest cause based on Anatomical Pathology data in 2010 with an incidence of $12.7 \% .{ }^{13}$ According to current estimates of the Indonesian Ministry of Health, every year there are 40,000 cases of cervical cancer in Indonesia. ${ }^{14}$

Early symptoms of cervical cancer are abnormal vaginal discharge, pain during intercourse, and menstruation in greater amounts or in a longer duration. Meanwhile, the advanced symptoms of cervical cancer are abnormal vaginal discharge, bleeding outside the menstrual cycle, bleeding after intercourse, menstruation in greater amounts or in a longer duration, and abdominal pain..$^{15}$

\section{Chronic cervical cancer pain and radiotherapy}

Radiotherapy has been contributing to cervical cancer (stage IA2-IVB) therapy since decades ago as adjuvant, palliative, or definitive treatment. The following is management of cervical cancer invasive lesion according to its FIGO stage; Stage 0 could be treated with conization or cold knife technique. Stage IA1 could be treated with lymph vascular space invasion (LVSI) 
negative, if cancer have clear border, then conization could be performed, but if the border is unclear, re-conization or simple hysterectomy could be performed. Total hysterectomy could be considered if fertility is not of patient's concern. Stage IA2, IB1, IIA1 could be treated with radical hysterectomy with lymphadenectomy could be performed. If risk of metastasis to lymph node, parametrium metastasis, and other risk factors are present, it is better to add radiotherapy as adjuvant or chemoradiation. If the risk of metastasis to lymph node is present without other risk factors, external beam radiation therapy (EBRT) with brachytherapy could be given as adjuvant therapy. Stage IB2 and IIA2 could be treated with radical hysterectomy and pelvic lymphadenectomy or chemotherapy neoadjuvant to decrease the size of primary tumor and reduce risk of surgical complication. Stage IIB could be treated with chemoradiation, radiotherapy, chemotherapy neoadjuvant, along with radical hysterectomy and pelvic lymphadenectomy. Other choice is to do ultra-radical hysterectomy. Stage IIIA, IIIB could be treated with chemoradiation and/or radiation. Stage IIIB with chronic kidney disease could be treated with nephrostomy/hemodialysis as needed, chemoradiation with non-cisplatin or only radiation. For stage IVA, IVB with chronic kidney disease patients, colostomy with palliative chemoradiation or palliative radiation could be done. If patient is stage IVA with chronic kidney disease, or stage IVB, palliative therapy such as chemotherapy or radiotherapy could be done if there is no contraindication. ${ }^{16}$ Radiation therapy is one of the treatments for cancer that use high dose radiation to kill the cancer cell and shrink tumors. Radiotherapy use radiation (X-ray and gamma-ray) and other particles. In low dose, radiation can be used to get X-ray image. Radiotherapy works by damaging the cancer cell's DNA. This damage was done by photon, electron, proton, neutron, or X-ray that whether directly or indirectly ionized the chain of cancer cell's DNA. Radiation to the tissue may cause ionization of water and electrolyte from body fluid, either intracellular or extracellular, causing ionization of water and electrolyte that will become very reactive. Those ions will react with the DNA molecules inside the chromosome, causing the breakage of DNA's double strings, changes in DNA's chain cross-linkage and degeneration or cell death. ${ }^{17}$

In the beginning, injury to healthy cells induce a response of hypersensitivity in long term. Damage to nerves, tissue, cells, and inflammation causes hyperalgesia or pain hypersensitivity. This can be caused by a long-term hyperexcitability of sensory neurons. It manifests in the form of the increasing release of potential energy in normal condition. A study of immune cytochemistry explained that red blood cells has an antigen of TGF $\beta 1$ which can detect antibodies. When local inflammation is detected by the neurons, red blood cells containing TGF $\beta 1$ near the site of damaged cells will release $28-\mathrm{kD}$ polypeptide, then will activate the antibody mechanism. Combination of antigen and antibody TGF $\beta 1$ will decrease pain tolerance at nociseptor. ${ }^{18}$ This process is called hypersensitivity. Hypersensitivity can be differentiated into allodynia and hyperalgesia. Allodynia is a pain responding to stimulus that shouldn't have affected nociceptive neurons. On the other hand, hyperalgesia is the increasing sensitivity of pain in response to nociceptive stimulus. ${ }^{19}$

A study on cervical cancer survivors stated that 35 out of 92 patients $(38 \%)$ had chronic pelvic pain. Beside pain, the significantly lower quality of life, higher anxiety, depression, bladder and intestinal problems are complained by cervical cancer patient survivors. ${ }^{20}$ Chronic pain is described as pain that is ongoing or reoccurs, and lasts more than acute pain or more than it normally takes to recover an injury, that could cause adverse effects in somebody's health. A simple description is pain that continues when it should not. Chronic pain could be classified as nociceptive, neuropathic, or combined. ${ }^{21}$ It happens in one or more anatomical location that is consistent for more than three months and related to emotional pressure or disturb daily activities. ${ }^{22}$

Pain that is not adequately managed results in what supposed to be avoidable suffering, decreased body function, disturbed sleep pattern, decrease appetite, and related to decreased quality of life in psychological and spiritual aspects. Patients who are suffering from pain has a tendency to decline any new therapy that offered by clinician if it potentially causes more pain. ${ }^{23}$

Patients with pain that is left untreated are exposed to emotional distress (anxiety, depression, anger, frustration, and resentment) and higher risk to develop Post Traumatic Stress Disorder (PTSD) symptoms. ${ }^{24}$

\section{Treatment}

According to American Society of Anesthesiologists Task Force and American Society of Anesthesia and Pain Medicine, there are several ways to manage chronic pain. First of all, history and physical examination is mandatory to find possible cause and early suspicion of chronic pain. Next, multidisciplinary or single modality interventions are performed. Ablative techniques, acupuncture, blocks, botulinum toxin injections, electrical nerve stimulation, epidural steroids, intrathecal drug therapies, minimally invasive spinal procedures, pharmacologic management, physical or restorative therapy, psychologic treatment, and trigger point injections have been proven to improve chronic pain..$^{25}$

Pharmacology is widely used for chronic pain management. In order to reduce unnecessary opioid consumption and reduce opioid abuse, medical workers are advised to limit prescription of narcotic analgesics and limit continuous prescription with periodical evaluation of pain complains and increase functional ability of patient instead. ${ }^{26}$

Guideline for pharmacologic pain management according to World Health Organization Ladder (WHO Ladder). First ladder for mild to moderate pain, start with non-opioid analgesics and increase the dose to maximum dose if needed. Add adjuvants such as anti-depressants and anti-convulsant if needed. If patient complain moderate or severe pain, go to second ladder. Second ladder means 
to add opioid for moderate pain such as hydrocodone (mixed with acetaminophen), add or continue adjuvants. If patient complains have not decreased after second ladder, go to third ladder. Third ladder means switch to opioid that is not mixed with other agents such as acetaminophen, add or continue adjuvants, adjusted to each individual; pain management can be adjusted to each individual according to their needs. ${ }^{27}$

Analgesic drugs are chemicals that suppress the function of central nervous system selectively, used to decrease pain without reducing awareness. Analgesic works by elevating pain threshold. According pharmacology classification, analgesics are divided into 2 groups; opioid analgesic and non-opioid analgesic. ${ }^{28}$

Table 1. Opioid analgesics. ${ }^{28}$

\begin{tabular}{llll} 
Strong Agonist & $\begin{array}{l}\text { Mild- } \\
\text { moderate } \\
\text { agonist }\end{array}$ & $\begin{array}{l}\text { Combination of } \\
\text { agonist- } \\
\text { antagonist }\end{array}$ & Antagonist \\
\hline Mophin & Codeine & Nalbuphine & Nalorphine \\
\hline Hidromorphine & Oxycodone & Buprenorphin & Naloxone \\
\hline Oksimorphin & Hydrocodone & Butorfanol & Naltrexone \\
\hline Metadone & Propoksiphen & Pentazosine & \\
\hline Meperidine & Didenoksilat & & \\
\hline Fentanil & & & \\
\hline Levorfanol & & & \\
\hline
\end{tabular}

Pain increases along with strong chemical or mechanic stimulus that is transmitted by sensory neurons. Nociceptor releases P substance and glutamate to dorsal ganglion root at spine. This information travels to brain through spinothalamic tract. As result, midbrain will send signal to inhibit dorsal root ganglion. Opioid receptors are classified into $\kappa$ (Kappa), $\mu(\mathrm{Nu}), \delta$ (Delta) that locates along nervous system, including main afferent neurons, spinal neurons, midbrain, and thalamus. Major mechanism of opioid drugs is inhibiting the release of neurotransmitter from terminal of dorsal root ganglion in spine and concurrently activate midbrain to activate inhibition of dorsal ganglion root. When opioid receptors are coupled with opioid, several reactions that occurs are: inhibition of calcium channel therefore inhibiting depolarization and neurotransmitter is not released, increasing kalium ion release therefore hyperpolarization happens on the postsynaptic and inhibition happens along the nervous system; inhibition of adenylate cyclase which is an enzyme that break adenosine triphosphate to cyclic adenosine monophosphate therefore inhibits the release of neurotransmitter. ${ }^{29}$

Analgesics non opioid or non steroid anti inflammation drug (NSAID) that have analgesics effect are: aspirin (acetylsalicylic acid), paracetamol (acetaminophen), mefenamic acid, ketoprofen, ibuprofen, naproxen, dexketoprofen trometamol, piroxicam and meloxicam. These drugs work by limiting cyclooxygenase enzyme therefore conversion of arachidonate acid to prostaglandin-endoperoxides synthase 2 (PPG-2) is blocked. Each drugs limit cyclooxygenase with different strength and selectivity. ${ }^{28}$

\section{References}

1. Levy MH, Chwistek M, Mehta RS. Management of chronic pain in cancer survivors. Cancer J. 2008;14(6):401-9. DOI: 10.1097/PPO.0b013e31818f5aa7

2. Kwon JW, Huh SJ, Yoon YC, et al. Pelvic bone complications after radiation therapy of uterine cervical cancer: Evaluation with MRI. Am J Roentgenol. 2008;191(4):987-94. DOI: 10.2214/AJR.07.3634

3. Baxter NN, Habermann EB, Tepper JE, et al. Risk of pelvic fractures in older women following pelvic irradiation. J Am Med Assoc. 2005 23;294(20):2587-93. DOI: 10.1001/jama.294.20.2587

4. Vistad I, Kristensen GB, Fosså SD, et al. Intestinal malabsorption in long-term survivors of cervical cancer treated with radiotherapy. Int J Radiat Oncol Biol Phys. 2009;73(4):1141-7. DOI: 10.1016/j. ijrobp.2008.05.064

5. Vistad I, Cvancarova M, Kristensen GB, et al. A study of chronic pelvic pain after radiotherapy in survivors of locally advanced cervical cancer. J Cancer Surviv. 2011;5(2):208-16. DOI: 10.1007/s11764-011-0172-z

6. Bergmark K, Åvall-Lundqvist E, Dickman PW, et al. Patient-rating of distressful symptoms after treatment for early cervical cancer. Acta Obstet Gynecol Scand. 2002;81(5):443-50. DOI: 10.1034/j.16000412.2002.810512.x

7. Bismar MM, Sinicrope FA. Radiation enteritis. Current gastroenterology reports. 2002;4:361-5. DOI: 10.1007/s11894-002-0005-3

8. McMahon S, Koltzenburg M, Tracey I, et al. Cancer pain. In: Wall and Melzack's textbook of pain. $5^{\text {th }}$ ed. Philadelphia: Elsevier/Churchill Livingstone; 2005:1120.

9. Cervical cancer treatment (PDQ)-Patient Version. National Cancer Institute. Available at : https://www.cancer.gov/types/cervical/patient/cervical-treatment-pdq\#section/all. Accessed January 28, 2020.

10. Forouzanfar M, Foreman K, Delossantos A, et al. Breast and cervical cancer in 187 countries between 1980 and 2010: A systematic analysis. The Lancet. 2011;378(9801):1461-84.

11. Aswathy S, Reshma J, Avani D. Epidemiology of cervical cancer with special focus on India. International Journal of Women's Health. 2015;7:405-14. DOI: 10.2147/IJWH.S50001

12. Ferlay J, Soerjomataram I, Dikshit R, et al. Cancer incidence and mortality worldwide: Sources, methods and major patterns in GLOBOCAN 2012. International Journal of Cancer. 2014;136(5):E359-86.

13. Commemorating its 18th anniversary, UPH Faculty of Medicine Provides Free Cervical Cancer Service. University of Pelita Harapan. Available at: https://www.uph.edu/2019/10/26/peringati-diesnatalis-ke-18-fk-uph-beri-layanan-pemeriksaan-kanker-serviks-gratis/

14. Profil Kesehatan Indonesia Tahun 2017. Indonesian Ministry of Health. Available at: https://www.depkes.go.id/resources/download/pusdatin/ profil-kesehatan-indonesia/Profil-Kesehatan-Indonesia-tahun-2017.pdf. Accessed January 28, 2020.

15. Papadopoulou I, Stewart V, Barwick T, et al. and Bharwani N. Post-Radiation Therapy Imaging Appearances in Cervical Carcinoma. RadioGraphics, 2016;36(2):538-553. 
16. Andrijono, Purwoto G, Sekarutami SM, et al. Guideline for cervical cancer management 2017. Comitee of National Cancer Prevention. Indonesian Ministry of Health. Available at: http://kanker.kemkes.go.id/ guidelines/PPKServiks.pdf

17. Baskar R, Le K, Yeo R, et al. Cancer and radiation therapy: current advances and future directions. International Journal of Medical Sciences. 2012;9(3):193-9. DOI: 10.7150/ijms.3635

18. Baskar R, Dai J, Wenlong N, et al. Biological response of cancer cells to radiation treatment. Frontiers in Molecular Biosciences. 2014;1:24 DOI: $10.3389 /$ fmolb.2014.00024

19. Treede R. The International Association for the Study of Pain definition of pain: as valid in 2018 as in 1979, but in need of regularly updated footnotes. PAIN Reports. 2018;3(2):e643. DOI: 10.1097/ PR9.0000000000000643

20. Vistad I, Cvancarova M, Kristensen G, et al. A study of chronic pelvic pain after radiotherapy in survivors of locally advanced cervical cancer. Journal of Cancer Survivorship. 2011;5(2):208-16. DOI: 10.1007/ s11764-011-0172-Z

21. Toolkit for Healthcare Professionals: Activities and Resources. American Chronic Pain Association. Available at: https://theacpa.org/uploads/ Health_Care_Profressional_Tool_kit_2016.pdf

22. Treede RD, Rief W, Barke A, et al. A classification of chronic pain for ICD-11. Pain. 2015;156(6):1003-7. DOI: 10.1097/j. pain. 0000000000000160 .
23. Namukwaya E, Leng M, Downing J, et al. Cancer Pain Management in Resource-Limited Settings: A Practice Review. Pain Research and Treatment. 2011;2011:393404. DOI: 10.1155/2011/393404

24. Lang E, Liebig K, Kastner S, et al. Multidisciplinary rehabilitation versus usual care for chronic low back pain in the community: Effects on quality of life. The Spine Journal. 2003;3(4):270-6. DOI: 10.1016/ s1529-9430(03)00028-7

25. Williams L, Wilkins. Practice guidelines for chronic pain management. Anesthesiology, 2010;112(4):810-33. DOI: 10.1097/ALN 0b013e3181c43103

26. Forouzanfar M, Foreman K, Delossantos A, et al. Breast and cervical cancer in 187 countries between 1980 and 2010: A systematic analysis. The Lancet. 2011;378(9801):1461-84. DOI: 10.1016/S0140$6736(11) 61351-2$

27. Guiloff R, Angus-Leppan H. WHO analgesic ladder and chronic pain: the need to search for treatable causes. BMJ. 2016;352:1597. DOI: 10.1136/bmj.i597

28. Nurmayanti F. Profil penggunaan analgesik dalam menghilangkan nyeri pasien kanker organ reproduksi wanita di RSUP Fatmawati tahun 2012. Medical Faculty, Department of Pharmacology. Jakarta. 2012;9-14.

29. Chahl L. Experimental and Clinical Pharmacology: Opioids - mechanisms of action. Australian Prescriber. 1996;19(3):63-5. DOI: 10.18773/ austprescr.1996.063 